\title{
KANDUNGAN ANTIOKSIDAN PADA RUMPUT LAUT Eucheuma spinosum YANG DIEKSTRAK DENGAN METANOL DAN ETANOL
}

\author{
Alindra Podungge ${ }^{1}$, Lena J. Damongilala ${ }^{2}$, Hanny W. Mewengkang ${ }^{2}$ \\ ${ }^{1)}$ Mahasiswa pada Program Studi Teknologi Hasil Perikanan FPIK Unsrat Manado \\ ${ }^{2)}$ Staf pengajar pada Program Studi Teknologi Hasil Perikanan FPIK Unsrat Manado \\ Email: alindrainda_podungge@yahoo.com
}

\begin{abstract}
Seaweed or algae known as seaweed is the largest part of the marine plant. Seaweed is a low level plant that does not have differences in skeletal arrangement such as true root, stem, and leaf and is better known as thallus plant. The purpose of this study was to determine the phytochemical content of Eucheuma spinosum seaweed and Eucheuma denticulatum seaweed antioxidant activity through DPPH (1,1-diphenyl-2-picrylhidrazyl) test. The result of E. spinosum seaweed extract sample was obtained from the initial weight difference of $1,500 \mathrm{gr}$ seaweed. Then the evaporator get the result of each that is Methanol 50\%=23.75 gr, methanol $95 \%=17.71 \mathrm{gr}$, ethanol $50 \%=27.67 \mathrm{gr}, 95 \%$ ethanol=18.51 gr. After obtaining the initial weight and weight result after evaporation, the calculation of yield and yield methanol $50 \%=1.6 \%$, methanol $95 \%=1.2 \%$, ethanol $50 \%=1.8 \%$ and ethanol $95 \%=1.2 \%$. The antioxidant activity on seaweed E. spinosum uses 2 types of solvents ie methanol and ethanol at concentrations of $50 \%$ and $95 \%$ each with $\mathrm{IC}_{50}$, methanol 50\%=223.305, methanol $95 \%=238.128$, ethanol 50\%=113.882, ethanol $95 \%=97.522$. Phytochemical test results of seaweed extract E. spinosum with methanol solvent and ethanol. At concentrations of $50 \%$ and $95 \%$ ethanol produce $(+)$ or color formation in the alkaloid compounds, steroids, polyphenols and flavonoids. While the concentration of methanol $50 \%$ yields $(+)$ on alkaloid compound group, steroid, saponin, polyphenol, flavonoid and at $95 \%$ concentration yield $(+)$ from six groups of tested compounds ie alkaloids, steroids, saponins, terpenoids, polyphenols and flavonoids.
\end{abstract}

Keyword: $\quad$ Antioxidant, Seaweed, Eucheuma spinosum, Methanol, Ethanol.

\begin{abstract}
ABSTRAK
Rumput laut atau algae dikenal dengan nama seaweed merupakan bagian terbesar dari tanaman laut. Rumput laut adalah tanaman tingkat rendah yang tidak memiliki perbedaan susunan kerangka seperti akar, batang, dan daun yang sejati dan lebih dikenal dengan nama tumbuhan talus. Tujuan Penelitian ini adalah untuk mengetahui kandungan fitokimia pada rumput laut Eucheuma spinosum dan aktivitas antioksidan rumput laut Eucheuma denticulatum melalui uji DPPH (1,1-diphenyl-2picrylhidrazyl). Hasil sampel ekstrak rumput laut E. spinosum diperoleh dari selisih berat awal rumput laut 1.500 gr. Kemudian dilakukan evaporasi mendapatkan hasil masing-masing yaitu Metanol $50 \%=23,75 \mathrm{gr}$, metanol $95 \%=17,71 \mathrm{gr}$, etanol $50 \%=27,67 \mathrm{gr}$, etanol $95 \%=18,51 \mathrm{gr}$. Setelah mendapat hasil berat awal dan hasil berat setelah dievaporasi dilakukan perhitungan rendemen dan menghasilkan berat metanol $50 \%=1,6 \%$, metanol $95 \%=1,2 \%$, etanol $50 \%=1,8 \%$ dan etanol $95 \%=1,2 \%$. Aktivitas antioksidan pada rumput laut $E$. spinosum menggunakan 2 jenis pelarut yaitu metanol dan etanol pada konsentrasi masing-masing 50\% dan 95\% ditandai dengan nilai $\mathrm{IC}_{50}$, metanol 50\%=223,305, metanol $95 \%=238,128$, etanol $50 \%=113,882$ dan etanol $95 \%=97,522$. Hasil uji fitokimia ekstrak rumput laut $E$. spinosum dengan pelarut metanol dan etanol. Pada konsentrasi etanol 50\% dan 95\% menghasilkan (+) atau terbentuknya warna pada golongan senyawa alkaloid, steroid, polifenol dan flavonoid. Sedangkan pada konsentrasi metanol 50\% menghasilkan (+) pada golongan senyawa alkaloid, steroid, saponin, polifenol, flavonoid dan pada konsentrasi $95 \%$ menghasilkan $(+)$ dari keenam golongan senyawa yang di uji yaitu alkaloid, steroid, saponin, terpenoid, polifenol dan flavonoid.
\end{abstract}

Kata Kunci: Antioksidan, Rumput laut, Eucheuma spinosum, Metanol, Etanol.

\section{PENDAHULUAN}

Rumput laut atau algae dikenal dengan nama seaweed merupakan bagian terbesar dari tanaman laut. Rumput laut adalah tanaman tingkat rendah yang tidak memiliki perbedaan susunan kerangka seperti akar, batang dan daun yang sejati dan lebih dikenal dengan nama tumbuhan talus (Berhimpon, 2001). Masyarakat menggunakan rumput laut hanya sebagai sayuran dan bahan yang tidak berbahaya untuk dimakan. Dengan berjalannya waktu, pengetahuan 
tentang rumput laut pun semakin berkembang. Orang semakin tahu apa yang terkandung dalam rumput laut (Indriani dan Sumarsih 1999). Kandungan utama rumput laut segar adalah air yang mencapai $80-90 \%$, sedangkan kadar protein dan lemaknya sangat kecil. Walaupun kadar lemak rumput laut sangat rendah, susunan asam lemaknya sangat penting bagi kesehatan. Lemak rumput laut mengandung asam lemak omega-3 dan omega-6 dalam jumlah yang cukup tinggi. Kedua asam lemak ini merupakan asam lemak yang penting bagi tubuh, terutama sebagai pembentuk membran jaringan otak, syaraf, retina mata, plasma darah dan organ reproduksi. Seratus (100) gram rumput laut kering mengandung asam lemak omega-3 berkisar 128-1.629 $\mu \mathrm{g}$ dan

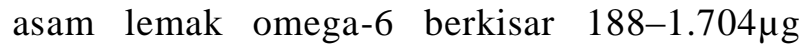
(Winarno,1990).

Manfaat lain dari rumput laut yaitu sebagai sumber antioksidan alami, antioksidan berdasarkan sumbernya dibagi menjadi dua yaitu antioksidan alami dan antioksidan sintesis. Antioksidan sintesis telah banyak digunakan, namun penggunaan dalam jumlah berlebihan dapat menimbulkan efek samping (Cahyadi, 2006).

Antioksidan primer yaitu sebagai antioksidan utama pemberi atom hidrogen $(\mathrm{AH})$, karena senyawa ini memberikan atom hidrogen secara cepat ke senyawa radikal, dimana radikal yang terbentuk menghasilkan derivat lipida dan radikal antioksidan $(\mathrm{A} *)$. Peranannya sebagai donor atom hidrogen pada radikal bebas lemak untuk membentuk kembali molekul lemak. Dengan demikian jika antioksidan diberikan mencegah pembentukan radikal baru, maka akan menghambat proses autooksidasi (Dewanti, 2006; Eitenmiller, 2008).

Antioksidan sekunder disebut juga antioksidan non enzimatis atau eksogenus yaitu kelompok senyawa yang berperan dalam system pertahanan preventif. Antioksidan ini dapat mengkelat logam prooksidan dan mendeaktifasinya. Pengkelatan terjadi dalam sistem cairan ekstraseluler. Antioksidan sekunder disebut juga antioksidan non enzimatis atau eksogenus yaitu kelompok senyawa yang berperan dalam sistem pertahanan preventif. Antioksidan ini dapat mengkelat logam prooksidan dan mendeaktifasinya. Pengkelatan terjadi dalam sistem cairan ekstraseluler.

\section{METODOLOGI PENELITIAN}

\section{Waktu dan Tempat Penelitian}

Penelitian ini sudah dilakukan di Laboratorium Teknologi Penanganan dan Pengolahan Hasil Perikanan dan Laboratorium Pengendalian Mutu Hasil Perikanan, Fakultas Perikanan dan Ilmu Kelautan untuk pemisahan senyawa antioksidan yaitu ekstraksi dan maserasi, kemudian diuji lanjut Fitokimia dan Kandungan antioksidan metode DDPH (1,1-Diphenyl-2picryhydrazyl) di Laboratorium FMIPA Universitas Sam Ratulangi Manado.

\section{Bahan dan Alat Penelitian}

Bahan baku E. spinosum, akuades, etanol $\left(\mathrm{C}_{2} \mathrm{H}_{5} \mathrm{OH}\right)$, methanol pa $\left(\mathrm{CH}_{3} \mathrm{OH}\right)$, nheksan, DPPH (1,1-Diphenyl-2-picryhydrazyl), $\mathrm{HCl}, \mathrm{FeC}_{13}, \mathrm{Mg}$, kloroform, mayer, wagner, dragondorfft, Asam Asetat Glasial, $\mathrm{H}_{2} \mathrm{SO}_{4}$.

Peralatan yang digunakan dalam penelitian: jergen penampung, toples perendam, pompa, kertas saring, aluminium foil, tissue dapur, pisau, gunting, loyang, botol bertutup untuk maserasi, rotary vacuum evaporator, timbangan digital, freeze dryer, cabinet dryer, spectrophotometer UV, lampu UV, autoclave, sentrifuge, peralatan gelas, vacuum, tabung reaksi, gelas ukur, pipet tetes dan pipit mikro.

\section{Proses Ekstraksi}

Langkah-langkah ekstraksi sampel yang dilakukan adalah sebagai berikut:

a. Rumput laut E. spinosum segar dicuci bersih dan ditiriskan.

b. E. spinosum dipotong-potong kecil dan ditimbang sebanyak 500 gr, lalu dimasukkan ke dalam masing-masing toples, kemudian ditambahkan pelarut metanol dan etanol di setiap toples dengan perbandingan $1: 1(\mathrm{w} / \mathrm{v})$.

c. Maserasi selama 3x24 jam pada suhu.

d. Hasil maserasi kemudian disaring dengan kertas saring Whatman no. 42 sehingga dihasilkan filtrat dan residu. Filtrat disimpan untuk perlakuan selanjutnya.

e. Filtrat dievaporasi dengan Vakuum rotary evaporator pada suhu $40^{\circ} \mathrm{C}$ hingga diperoleh ekstrak kental.

f. Ekstrak kental yang diperoleh dihitung persentase rendemen dan selajutnya dilakukan uji fitokimia dan uji aktivitas antioksidan dengan metode DPPH.

\section{Analisis Data}

Hasil pengamatan laboratorium dilakukan 2 cara yaitu pengamatan yang bersifat kua- 
litatif dan kuantitaf. Pengamatan yang bersifat kualitatif yaitu uji fitokimia yang disajikan dalam bentuk tabel sedangkan kuantitatif data yang diperoleh dari nilai absorbansi untuk uji aktivitas antioksidan selanjutnya dilakukan perhitungan dengan nilai rata-rata dengan menggunakan rumus persen hambatan radikal bebas, lalu menggunakan persamaan regresi, yang hasilnya disajikan dalam bentuk tabel dan kurva.

\section{Parameter Yang Diuji}

Parameter yang diuji adalah menghitung rendemen, Pengujian aktivitas antioksidan metode DPPH dan Uji Fitokimia.

\section{Rendemen (AOAC 1995)}

Rendemen diperoleh dari perbandingan berat kering gelatin yang dihasilkan dengan berat bahan segar yang digunakan. Pada bahan pangan, semakin tinggi nilai rendemen yang dihasilkan maka semakin ekonomis bahan pangan. Besarnya rendemen dapat diperoleh dengan menggunakan rumus sebagai berikut:

$$
\% \text { Rendemen }=\frac{\text { Bobot Ekstrak }}{\text { Bobot Sampel Awal }} \times 100 \%
$$

\section{Uji Kandungan Fitokimia (Suzery dan Kusrini, 2004)}

Ekstrak dilarutkan dalam $5 \mathrm{ml}$ etanol. 1 $\mathrm{ml}$ tiap ekstrak ditambah $5 \mathrm{ml}$ dicampur kloroform dan air suling (1:1) lalu dikocok dan larutan dibiarkan beberapa saat ( \pm 5 menit). Lapisan kloroform di bagian bawah digunakan untuk pemeriksaan senyawa steroid dan triterpenoid sedangkan lapisan air untuk pemeriksaan senyawa flavonoid dan saponin.

a. Uji senyawa flavonoid

Lapisan air $( \pm 2 \mathrm{ml})$ dari tahap preparasi di atas diambil dan dimasukkan ke dalam tabung reaksi. Kemudian ditambahkan 1-2 butir logam magnesium dan 3 tetes asam klorida pekat $(\mathrm{HCl})$. Sampel positif mengandung flavonoid jika terbentuk warna orange hingga merah.

b. Uji senyawa saponin

Lapisan air $( \pm 2 \mathrm{ml})$ dari tahap preparasi di atas diambil dan dimasukkan ke dalam tabung reaksi kemudian larutan dikocok kuat-kuat. Sampel positif mengandung senyawa saponin apabila terbentuk busa yang permanen yang tidak hilang dalam waktu 15 menit.

c. Uji senyawa alkaloid
Lapisan kloroform ditambahkan 10 tetes asam sulfat pekat $\left(\mathrm{H}_{2} \mathrm{SO}_{4}\right)$ dan dikocok perlahan, dibiarkan sampai terbentuk lapisan asam. Lapisan asam (bagian di bawah cincin bening yang berbentuk dari penambahan asam sulfat) diambil dan ditambah satu tetes pereaksi Meyer. Reaksi positif ditandai dengan kabut putih.

d. Uji senyawa steroid dan triterpenoid Lapisan kloroform dari tahap preparasi diambil dan dimasukkan ke pipet Pasteur yang didalamnya sudah ada arang. Filtrat yang sudah keluar dari pipet Pasteur dimasukkan ke dalam 3 buah lubang pada plat tetes ditambahkan satu tetes asam asetat anhidrat $\left(\left(\mathrm{CH}_{3} \mathrm{CO}\right) 2 \mathrm{O}\right)$ dan satu tetes asam sulfat pekat $\left(\mathrm{H}_{2} \mathrm{SO}_{4}\right)$. Sampel positif mengandung senyawa steroid ditunjukkan dengan warna biru sampai ungu sedangkan sampel positif mengandung senyawa triterpenoid jika ditunjukkan dengan warna merah.

e. Uji senyawa fenolik

Lapisan air dari tahap preparasi di atas diambil dan dimasukkan ke dalam plat tetes. Kemudian ferri klorida pada tiap plat tetes yang telah diberi sampel. Adanya senyawa fenolik ditandai dengan terbentuknya warna biru atau ungu.

\section{Uji DPPH (Banerjee $d k k$., 2005)}

Sampel ekstrak dengan berbagai konsentrasi $(50,100,150,200,250,300,350$ dan $400 \mathrm{ppm})$ diambil sebanyak $3 \mathrm{ml}$ dimasukkan ke dalam tabung reaksi yang sudah dibungkus alumunium foil kemudian ditambahkan $1 \mathrm{ml}$ larutan DPPH 0,004\%. Larutan dikocok sampai homogen dan dibiarkan selama 30 menit dalam suhu ruang.

Absorbansinya diukur pada panjang gelombang $517 \mathrm{~nm}$ menggunakan spektrofotometer UV-Visible. Nilai persentase inhibisi (penghambatan) yang diwakili oleh nilai $\mathrm{C}_{50}$ dihitung dengan rumus sebagai berikut:

$$
\frac{\text { Abs DPPH-Abs Ekstrak }}{\text { Abs DPPH }} \times 100 \%
$$

\section{HASIL DAN PEMBAHASAN}

\section{Rendemen Ekstrak Rumput Laut Eucheuma spinosum}

Nilai rendemen ekstrak rumput laut $E$. spinosum dengan 2 jenis pelarut yaitu metanol dan etanol dengan konsentrasi masing-masing yaitu $50 \%$ dan $95 \%$. Data hasil penelitian me- 
nunjukkan bahwa konsentrasi pelarut etanol dan metanol 50\% mampu menghasilkan rendemen ekstrak E. spinosum tertinggi dibandingkan dengan konsentrasi pelarut etanol dan metanol 95\%. Hasil rendemen ekstrak E. spinosum dapat dilihat pada tabel 1 .

Tabel 1. Hasil Rendemen dari Masing-Masing

\begin{tabular}{ccc}
\multicolumn{3}{c}{ Sampel Eucheuma spinosum. } \\
\hline Ekstrak & $\begin{array}{c}\text { Warna } \\
\text { (Ekstrak Pekat) }\end{array}$ & $\begin{array}{c}\text { Rendemen (\%) } \\
\text { Ekstrak }\end{array}$ \\
\hline Metanol 50\% & Merah Muda & $1,6 \%$ \\
Metanol 95\% & Hijau & $1,2 \%$ \\
Etanol 50\% & Merah Muda & $1,8 \%$ \\
Etanol 95\% & Hijau & $1,2 \%$ \\
\hline
\end{tabular}

Hasil sampel ekstrak E. spinosum diperoleh dari selisih berat awal rumput laut $1.500 \mathrm{gr}$. Kemudian dilakukan evaporasi mendapatkan hasil masing-masing yaitu Metanol 50\% $=23,75$ gr, metanol $95 \%=17,71 \mathrm{gr}$, etanol $50 \%=27,67$ gr, etanol $95 \%=18,51 \mathrm{gr}$. Setelah mendapat hasil berat awal dan hasil berat setelah dievaporasi dilakukan perhitungan rendemen dan menghasilkan berat metanol $50 \%=1,6 \%$, metanol $95 \%=$ $1,2 \%$, etanol $50 \%=1,8 \%$ dan etanol $95 \%=1,2 \%$.

Kasminah (2016) nilai rendemen ekstrak Halymenia durvillaei dengan berbagai pelarut, terdapat tiga jenis pelarut yaitu etanol, etil asetat dan $\mathrm{n}$-heksan. Pelarut etanol mampu menghasilkan rendemen ekstrak $H$. durvillaei tertinggi dibandingkan dengan pelarut etil asetat dan n-heksan. Hasil rendemen ekstrak $H$. durvillaei pelarut etanol $=0,4142 \%$, pelarut etil asetat $=0,1085 \%$, dan $n$-heksan $=0,0208 \%$. Hasil rendemen ekstrak $H$. durvillaei diperoleh dari selisih berat ekstrak dengan berat simplisia $H$. durvillaei. Berat simplisia awal rumput laut $H$. durvillaei adalah $200 \mathrm{gr}$.

\section{Aktivitas Antioksidan Rumput Laut Eucheuma spinosum}

Aktivitas antioksidan dari E. spinosum menggunakan dua jenis pelarut yaitu metanol dan etanol ditandai dengan nilai $\mathrm{IC}_{50}$. Nilai $\mathrm{IC}_{50}$ menunjukkan besarnya aktivitas antioksidan dalam konsentrasi larutan sampel untuk menghambat 50\% radikal bebas DPPH. Hasil pengujian aktivitas antioksidan dengan DPPH yang memiliki $\mathrm{IC}_{50}$ dari aktivitas antioksidan terkecil, berarti memiliki aktivitas antioksidan besar. Hasil $\mathrm{IC}_{50}$ dapat dilihat pada tabel 2.

Data hasil uji aktivitas antioksidan ekstrak rumput laut segar yang menggunakan pelarut metanol dan etanol dengan konsentrasi masing-masing menghasilkan Nilai $\mathrm{IC}_{50}$ terting- gi pada ekstrak yang menggunakan pelarut etanol.

Tabel 2. Aktivitas Antioksidan Penghambatan Radikal Bebas.

\begin{tabular}{ccr}
\hline Sampel (\%) & Konsentrasi (ppm) & IC $_{\mathbf{5 0}}$ \\
\hline Metanol 50 & $50,100,150,200,250$ & 223,305 \\
Metanol 95 & $50,100,150,200,250$ & 238,128 \\
Etanol 50 & $50,100,150,200,250$ & 113,882 \\
Etanol 95 & $50,100,150,200,250$ & 97,522 \\
\hline & & \\
\multicolumn{4}{c}{ Menurut $\quad$ Damongilala } & $(2014)$ & hasil
\end{tabular}
analisis data penghambatan radikal bebas DPPH menunjukkan bahwa pada semua kondisi sampel Eucheuma sp terdapat perbedaan nilai DPPH $(\mathrm{p}<0,05)$ pada konsentrasi pelarut metanol. E. spinosum segar memiliki nilai DPPH tertinggi diantara ke empat sampel yaitu $E$. spinosum segar, kering dan E. cottoni segar, kering pada kondisi sampel, yaitu sebesar 75,27 $\pm 0,29 \%$ pada konsentrasi pelarut metanol $60 \%$ menunjukkan bahwa kemampuan menangkal radikal DPPH dipengaruhi oleh besarnya konsentrasi ekstrak.

\section{Uji Fitokimia Ekstrak Rumput Laut}

Hasil penelitian terhadap uji fitokimia ekstrak E. spinosum dengan pelarut etanol dan metanol pada konsentrasi masing-masing 50 dan $95 \%$, menunjukkan keberadaan komponen senyawa yang terkandung.

Tabel 3. Uji Fitokimia Senyawa Aktif Pada Ekstrak Alga Merah Eucheuma spinosum.

\begin{tabular}{ccccc}
\hline \multirow{2}{*}{ Golongan } & \multicolumn{5}{c}{ Jenis Ekstrak } \\
\cline { 2 - 5 } Senyawa & $\begin{array}{c}\text { Metanol } \\
\mathbf{5 0 \%}\end{array}$ & $\begin{array}{c}\text { Metanol } \\
\mathbf{9 5 \%}\end{array}$ & $\begin{array}{c}\text { Etanol } \\
\mathbf{5 0 \%}\end{array}$ & $\begin{array}{c}\text { Etanol } \\
\mathbf{9 5 \%}\end{array}$ \\
\hline Alkoloid & + & + & + & + \\
Steroid & + & + & + & + \\
Saponin & + & + & - & - \\
Terpenoid & - & + & - & - \\
Polifenol & + & + & + & + \\
Flavonoid & + & + & + & + \\
\hline Ket.: + = Mengandung golongan senyawa. &
\end{tabular}

Hasil uji fitokimia ekstrak E. spinosum dengan pelarut metanol dan etanol. Pada konsentrasi etanol 50\% dan 95\% menghasilkan (+) atau terbentuknya warna pada golongan senyawa alkaloid, steroid, polifenol, flavonoid. Sedangkan pada konsentrasi metanol 50\% menghasilkan (+) pada golongan senyawa alkaloid, steroid, saponin, polifenol, flavonoid dan pada konsentrasi 95\% menghasilkan (+) dari keenam golongan senyawa yang diuji yaitu alkaloid, steroid, saponin, terpenoid, polifenol, flavonoid. 
Hasil uji fitokimia diskrining dan didapatkan tanin, terpenoid, steroid dan alkaloid pada ekstrak sampel seaweed Ulva fasciata dan Chaetomorpha antennina. Pada alga hijau $U$. reticulate Forskal menunjukkan adanya golongan senyawa triterpenoid dalam ekstraknya yang ditunjukkan dengan terbentuknya warna ungumerah pada sediaan setelah ditambahkan pereaksi Lieberman Bouchard (Tamat $d k k$., 2007).

\section{KESIMPULAN DAN SARAN}

\section{Kesimpulan}

1. Hasil sampel ekstrak rumput laut Eucheuma spinosum diperoleh dari selisih berat awal rumput laut $1.500 \mathrm{gr}$. Kemudian dilakukan evaporasi mendapatkan hasil masing-masing yaitu Metanol 50\%=23,75 gr, metanol $95 \%=17,71 \mathrm{gr}$, etanol $50 \%=27,67 \mathrm{gr}$, etanol $95 \%=18,51 \mathrm{gr}$. Setelah mendapat hasil berat awal dan hasil berat setelah dievaporasi dilakukan perhitungan rendemen dan menghasilkan berat metanol $50 \%=1,6 \%$, metanol $95 \%=1,2 \%$, etanol $50 \%=1,8 \%$ dan etanol $95 \%=1,2 \%$.

2. Aktivitas antioksidan pada rumput laut $E u$ cheuma spinosum menggunakan 2 jenis pelarut yaitu metanol dan etanol pada konsentrasi masing-masing 50\% dan $95 \%$ ditandai dengan nilai $\mathrm{IC}_{50}$, metanol $50 \%=223,305$, metanol $95 \%=238,128$, etanol $50 \%=$ 113,882 dan etanol $95 \%=97,522$.

3. Hasil uji fitokimia ekstrak rumput laut Eucheuma spinosum dengan pelarut metanol dan etanol. Pada konsentrasi etanol 50\% dan 95\% menghasilkan (+) atau terbentuknya warna pada golongan senyawa alkaloid, steroid, polifenol, flavonoid. Sedangkan pada konsentrasi metanol 50\% menghasilkan (+) pada golongan senyawa alkaloid, steroid, saponin, polifenol, flavonoid dan pada konsentrasi $95 \%$ menghasilkan (+) dari keenam golongan senyawa yang di uji yaitu alkaloid, steroid, saponin, terpenoid, polifenol, flavonoid.

\section{Saran}

Diharapkan agar dapat dilakukan penelitian selanjutnya tentang kandungan antioksidan pada rumput laut Eucheuma spinosum segar dan kering dengan konsentrasi $50 \%$ dan $95 \%$ yang di ekstrak dengan pelarut metanol, etanol dan alkohol.

\section{DAFTAR PUSTAKA}

AOAC.1995. Offical Methods of Analysis of The Association of Offical Analytical Chemists. Washington.

Banerjee, A., N. Dasgupta and B. De. 2005. In Vitro Study of Antioxidant Activity of syzigium Cumini Fruit. Journal Food Chemistry 90.727-733.

Berhimpon, S. 2001. Industri pangan hasil bernilai tinggi (Valuable Commodities) salah satu unggulan agroindustri Sulawesi Utara. Makalah yang dipresentasikan pada seminar Perhimpunan Ahli Teknologi Pangan Indonesia (PATPI) Manado, 25 Januari 2001.

Cahyadi. W. 2006. Analisis dan Aspek Kesehatan Bahan Tambahan Pangan. Bumi Aksara.

Damongilala. J. L, 2014. Karakteristik Senyawa Antioksidan Alga Eucheuma Cotonii dan Eucheuma spinosum Dari Perairan Pulau Nain Sulawesi Utara. Pasca Sarjana Universitas Brawijaya Malang. [Disertasi]. Malang

Dewanti, Tri., 2006. Alternatif Pengganti Formalin Pada Produk Pangan. Jakarta. Gramedia Pustaka.

Indriani, H. dan Sumarsih, E. 1999. Budidaya Pengolahan dan Pemasaran Rumput Laut. PT. Penebar Swadaya. Jakarta.

Kasminah. 2016. Aktivitas Rumput Laut Halymenia durvillaei Dengan Pelarut Non Polar, Semi Polar Dan Polar. Universitas Airlangga Surabaya.

Suzery, M. dan D, Kusrini. 2004. Buku Ajar Pemisahan dan Analisis Bahan Alam. FMIPA, UNDIP, Semarang, $131 \mathrm{hlm}$.

Tamat, S. R., T. Wikanta dan L. S. Maulina. 2007. Aktivitas Antioksidan dan Toksisitas Senyawa Bioaktif dari Ekstrak Rumput Laut Hijau Ulva reticulata Forsskal. Jurnal Ilmu Kefarmasian Indonesia, 5 (1): 31-36.

Winarno F.G. 1990. Teknologi Pengolahan Rumput Laut. Jakarta. PT Gramedia Pustaka Utama 